\title{
Performance of Peanut (Arachis hypogaea L.) as Influenced by Time of Planting Sweetpotato (Ipomoea batatas L.) as Intercrop
}

\author{
Bonievic P. Sarcol and Ulysses A. Cagasan \\ Department of Agronomy, Visayas State University, \\ Visca, Baybay City, Leyte 6521-A Philippines
}

\section{ABSTRACT}

One common approach to increase crop production is through multiple cropping systems. This study was conducted to (1) evaluate the growth and yield of peanut as influenced by time of planting sweetpotato as intercrop; (2) determine the appropriate time of planting peanut and sweetpotato that would give their respective optimum yields; and (3) determine the profitability of growing peanut in combination with sweetpotato as influenced by time of planting the crops in an intercropping scheme.

Results of the study showed that peanut's maturity, leaf area index (LAI), number of seeds $\operatorname{pod}^{-1}$ and number of pods plant ${ }^{-1}$ were significantly $(\phi<0.05)$ increased by the time of planting sweetpotato as intercrop. Sweetpotato planted later than peanut significantly $(\phi<0.05)$ improved the number of lateral vines plant $^{-1}$, length of main vine, and fresh herbage yield of sweetpotato. Yield and yield components and harvest index of sweetpotato were not significantly $(p<0.05)$ affected by the time of planting the crops.

A net income of Php 66,508.00 was obtained from plots planted with peanut + sweetpotato regardless of time of planting. All intercropping treatments had a leaf area index (LER) of greater than one which means that peanut and sweetpotato are a good combination in an intercropping scheme compared to planting peanut as monocrop.

Keywords: Intercropping system, monocropping, land equivalent ratio, growth and yield, time of planting the crops

\section{INTRODUCTION}

Peanut (Arachis bypogaea L.) is an underground pod-bearing plant which belongs to the family of Leguminosae. It is an herbaceous, annual type of plant that grows to a height of $20-60 \mathrm{~cm}$. Depending on the variety, the plants may grow upright and sideways with their sideward shoots to a breadth of $30-80 \mathrm{~cm}$.

Aside from being an excellent food source, peanut is an income generating crop to farmers. It is one of the major field legumes grown by farmers in Luzon, Visayas, and Mindanao. However, although peanut is produced throughout the country, the yield is not enough to meet the increasing demand for household and industrial uses. In the Philippines, eighty percent (80\%) of our peanut is coming 
from China as one of the biggest peanut-producing countries in the world.

Peanut is a favorite food, whether eaten alone as a snack food or mixed into candy, cookies, pies, and other bakery products. It also provides health benefits, can reduce cardiovascular disease due to their monounsaturated fat content, reduce the risk of colon cancer and weight loss. It is also a good source of vitamin E, niacin, folate, protein, manganese and antioxidants that are key to Heart-Health Benefits (Blomhoff et al., 2006).

Food scarcity is one of the major problems encountered in the country today due to increasing human population and reduction of arable lands. In this regard, it is important to employ measures to augment crop production.

One way of increasing crop production is the adoption of cropping systems such as crop rotation, relay cropping, and intercropping. Intercropping offers farmers the opportunity to engage nature's principle of diversity on their farms. Spatial arrangements of plants, planting rates, and maturity dates must be considered when planning to practice intercropping system. Intercrops can be more productive than growing monocrops. It aims to achieve maximum profit per unit land area per unit time because of the combined yields of the maincrop and the intercrop. This practice requires less labor especially in weeding because of minimum vacant space thus, less weeds would grow. There is also a low risk in practicing intercropping system since if one crop fails there is another crop that the farmers can harvest.

The maincrop and intercrop planted together should be of different characteristics to minimize possible competition for the different growth factors, such as light, nutrients, space, moisture, and others. Sweetpotato is generally known as survival crop for it grows even in marginal areas. However, continuous planting of the crop in monoculture in the same piece of land may require supplemental application of nitrogen-containing fertilizers to maximize root yield (Escalada et al., 1983).

Growing field legumes in association with sweetpotato is an excellent alternative management practice to supply the nitrogen content of the soil. However, it has not been established yet at what appropriate time of planting peanut and sweetpotato as intercrop for maximum yield of both crops. Hence, this study was conducted to (1) evaluate the growth and yield performance of peanut as influenced by time of planting sweetpotato as intercrop; (2) determine the appropriate time of planting peanut and sweetpotato that would give optimum yield, and (3) find out the profitability of growing peanut in combination with sweetpotato as intercrop.

\section{MATERIALS AND METHODS}

The experimental area was laid out in a Randomized Complete Block Design (RCBD) with three replications. Plot size was $5 \mathrm{~m}$ long and $4 \mathrm{~m}$ wide $(20 \mathrm{~m} 2)$. One meter alleyway was provided between treatment plots and replications to facilitate farm operations and data gathering. The treatments were designated as follows: $\mathrm{T}_{1}{ }^{-}$ Peanut alone; $\mathrm{T}_{2}$ - Sweetpotato alone; $\mathrm{T}_{3}$ - Peanut planted at the same time with sweetpotato; $\mathrm{T}_{4}$ - Peanut planted one (1) week before intercrop with sweetpotato; $\mathrm{T}_{5^{-}}$Peanut planted two (2) weeks before intercrop with sweetpotato; and $\mathrm{T}_{6}$ Peanut planted 3 weeks before intercrop with sweetpotato. 
Peanut was applied with 30-30-30 kg N, $\mathrm{P}_{2} \mathrm{O}_{5}, \mathrm{~K}_{2} \mathrm{O}$ ha ${ }^{-1}$ and sweetpotato 45-45$45 \mathrm{~kg} \mathrm{~N}, \mathrm{P}_{2} \mathrm{O}_{5} \mathrm{~K}_{2} \mathrm{O}$ ha $^{-1}$. Fertilizers were applied plot $^{-1}$ one (1) week after planting the crops following what was the specified in the treatments. Sweetpotato cuttings (NSIC Sp 25) at 25-30 cm long were prepared a day before planting. The cuttings were planted in furrows between peanut at a distance of $100 \mathrm{~cm}$ between rows and $25 \mathrm{~cm}$ between hills at one cutting per hill. Peanut seeds (BPI Pn 9) were planted in ridges at a distance of $100 \mathrm{~cm}$ × $20 \mathrm{~cm}$ between hills at $2-3$ seeds hill ${ }^{-1}$ as specified in the treatment. Initial and final soil analyses were determined to assess the nutrient left and contribute to the growth and yield of both crops.

Weeds were controlled by handweeding two (2) weeks and four (4) weeks after planting. Weevils were controlled using pheromone trap while other insect pests were controlled using Cymbush $5 \mathrm{EC}$ as chemical spray. Replanting of missing hills was done to both the maincrop and the intercrop. Hilling-up of peanut and sweetpotato was done 3 weeks after planting using bolo and shovel.

Harvesting was done when both crops reached their maturity periods. Peanut was harvested with the aid of a bolo to loosen the soil. Fully matured, filled and undamaged pods were considered marketable. Those pods that did not possess the said criteria were considered as non-marketable.

Storage roots of sweetpotato were dug out using bolo after cutting the vines from the base. Extra care was observed to avoid damage of fleshy roots during harvesting. The fleshy roots with a diameter of $2.5 \mathrm{~cm}$ and length of $6.5 \mathrm{~cm}$ or greater were considered as marketable and those that did not meet the said criteria were considered non-marketable.

Data Gathered

Agronomic and Yield Characteristics for Peanut (Main Crop)

Days from planting to flowering - This was determined by counting the number of days from planting up to the time when $90 \%$ of the plants in each plot shall have produced flowers.

Days from planting to maturity - This was determined by counting the number of days from planting to maturity. This was manifested by drying of stems and yellowing or shedding off of leaves.

Leaf Area Index (LAI) - This was determined at flowering stage by multiplying the length and the width measured at the longest and broadest part, of all the green and fully expanded leaves of five sample plants plot $^{-1}$.

Fresh Herbage Yield $\left(\mathrm{t} \mathrm{ha}^{-1}\right)$ - This was determined by weighing the vegetative portion of all the plants harvested within the inner rows of each plot excluding the two end hills in each rows.

Number of pods per plant - This was determined by counting the number of pods that developed from each of the five sample plants in each treatment plot at harvest.

Number of seeds per pod - This was determined by counting the number of seed that developed from 10 sample pods in each treatment plot.

Weight of 1,000 seeds (g) - This was obtained by weighing 1,000 clean and dried seeds taken randomly from the sample plants in each plot. 
Pod yield $\left(\mathrm{t} \mathrm{ha}^{-1}\right)$ - was obtained from all plants in the inner rows at each treatment plot. The pods were sundried to approximately 14\% moisture content before weighing.

\section{Agronomic and Yield Characteristics of Sweetpotato (Intercrop)}

Number of lateral vines per plant - This was determined by counting the number of primary lateral vines from five sample plants at harvest. The sum was divided by the number of sample plants.

Length of main vines at harvest $(\mathrm{cm})$ - This was measured from the base of the plant up to the shoot tip of the main vine of 10 sample plants from the inner rows in each treatment plot at harvest.

Leaf Area Index (LAI) - This was determined by computing the ratio of the leaf area to the area of a quadrat $(50 \times 50 \mathrm{~cm})$ two months after planting. Only those green and fully open leaves were measured. The total leaf area was computed by multiplying the length and the width of every leaves at its broadest portion then multiplied by a correction factor of 0.59 (Abordo, 1997).

Fresh Herbage Yield $\left(\mathrm{t} \mathrm{ha}^{-1}\right)$ - This was determined by weighing the vines and leaves of all the sample plants from the inner rows in each plot, excluding the end two plants at harvest.

Number of marketable and non-marketable roots plot $^{-1}$-This was obtained by counting separately the marketable and non-marketable roots per plot. Roots with at least 2.5 in diameter and $6.5 \mathrm{~cm}$ in length were considered as marketable. Roots that will not meet the said measurement and damage by pest were considered as non-marketable.

Weight of marketable and non-marketable roots $\left(\mathrm{t} \mathrm{ha}^{-1}\right)$ - This was obtained by weighing separately the marketable and non-marketable roots harvested from each treatment plot.

Total Root Yield $\left(\mathrm{t} \mathrm{ha}^{-1}\right)$-This was determined by adding the weights of marketable and non-marketable roots in each treatment plot.

\section{Other Parameters Gathered:}

Land Equivalent Ratio (LER) - It is the measure of the total land productivity in an intercropping scheme. This is expressed as the sum of the fractions of the yield of the crop in a mixture relative to that of monoculture. LER was computed using the formula;

$$
\mathrm{LER}=\frac{X i}{X j}+\frac{Y i}{Y j}
$$

Where:

Xi-yield of peanut in intercropping

$\mathrm{Xj}$-yield of peanut in monoculture

Yi- yield of sweetpotato in intercropping

$\mathrm{Yj}$-yield of sweetpotato in monoculture 


\section{Cost and Return Analysis}

The net income was determined per treatment plot to find out the most promising and economical treatment that will give the highest net return. This was done by subtracting the total expenses from gross income using the formula:

$$
\text { Net Return }=\text { Gross Income }- \text { Total Expenses }
$$

Where:

$$
\begin{aligned}
\text { Gross Income }= & \text { yield that were computed hectare }{ }^{-1} \text { basis } x \text { current } \\
& \text { price of the crop }\left(\mathrm{P} \mathrm{kg}^{-1}\right)
\end{aligned}
$$

\section{RESULTS AND DISCUSSION}

\section{Soil Chemical Properties}

Initial analysis showed that the experimental area had a pH of 6.39 with $1.62 \%$ organic matter, $0.11 \%$ total nitrogen, $12.74 \mathrm{ppm}$ of phosphorus and $272.03 \mathrm{ppm}$ of potassium. These results indicated that the soil was low in organic matter and nitrogen (Brady, 1990); slightly acidic, with deficient P but with adequate level of $\mathrm{K}$, Table 1 (PCARR, 1980).

Final soil analysis showed a slight decrease in soil $\mathrm{pH}$ from the initial value of 6.39 to 6.25 , extractable P from $12.74 \mathrm{ppm}$ to $0.32 \mathrm{ppm}$, while an increase was noted in $\mathrm{OM}$ from $1.62 \%$ to $1.72 \%$ total nitrogen from 0.11 to 0.12 , and exchangeable K from 272.03 ppm to 368.14 ppm.

Phosphorus showed a considerable reduction after harvest. This observation could be due to high plant uptake and assimilation (Badalucco and Kiukman, 2002). In the rhizophere, $P$ solubility might be increased due to secretion of organic acids by the roots and changes in the $\mathrm{pH}$ value, possibly resulting in an increased P uptake (Gecker and Meyer, 1995). Increase in OM could be due to decomposed leaves and other parts of the plants while decrease in soil $\mathrm{pH}$ may be due to plant residues that were still decomposing. Increase in nitrogen was due to nitrogen fixation done by peanut and the release of nitrogen rich plant residues decomposed upon maturity (USDA, 1998).

\section{Agronomic Characteristics of Peanut as the Main Crop}

Data on agronomic characteristics of peanut are shown in Table 2. Among the agronomic characteristics of peanut evaluated, only the number of days from planting to maturity and LAI were significantly $(\mathrm{p}<0.05)$ affected by the timing of planting sweetpotato as intercropped.

Peanut planted 3 weeks before sweetpotato as intercrop $\left(\mathrm{T}_{6}\right)$ enhanced the maturity of peanut compared to peanut alone $\left(T_{1}\right)$, However $T_{6}$ was comparable to Peanut planted 1 week and 2 weeks before sweetpotato as intercrop $\left(\mathrm{T}_{4}\right.$ and $\left.\mathrm{T}_{5}\right)$ and Peanut + sweetpotato planted at the same time $\left(T_{3}\right)$. Peanut alone $\left(T_{1}\right)$ matured comparably to peanut with sweetpotato intercrop planted at the same time, planted 1 and 2 weeks after peanut. Early maturation of peanut in $T_{6}$ (sweetpotato intercrop planted 3 weeks after peanut) might be due to the effect of competition on the 
growth factors between the maincrop and the intercrop, both crops were planted close to each other which enhanced their competitive ability to utilize limited growth components and since peanut was planted ahead, it utilized more growth factors than sweetpotato, and consequently promoted early maturity. This result confirms the findings of Davis (1989) that when peanut was planted ahead of sweetpotato, it matured early due to early development.

Table 1. Initial and final analyses of the soil planted with peanut as influenced by the time of planting sweetpotato as intercrop.

\begin{tabular}{lccccc}
\hline \multicolumn{1}{c}{ Soil analyses } & $\mathrm{pH}$ & $\begin{array}{c}\mathrm{OM} \\
(\%)\end{array}$ & $\begin{array}{c}\text { Total } \\
\text { Nitrogen } \\
(\%)\end{array}$ & $\begin{array}{c}\text { Extractable } \\
\mathrm{P}(\mathrm{ppm})\end{array}$ & $\begin{array}{c}\text { Exchangeable } \\
\mathrm{K}(\mathrm{ppm})\end{array}$ \\
\hline Initial & 6.39 & 1.62 & 0.11 & 12.74 & 272.03 \\
\hline Final & & & & & \\
Treatments & & & & & 388.750 \\
$\mathrm{~T}_{1}$ & 6.32 & 1.18 & 0.08 & 0.45 & 318.023 \\
$\mathrm{~T}_{2}$ & 6.88 & 0.75 & 0.06 & 0.25 & 367.975 \\
$\mathrm{~T}_{3}$ & 6.38 & 2.15 & 0.12 & 0.23 & 368.663 \\
$\mathrm{~T}_{4}$ & 5.73 & 2.09 & 0.16 & 0.29 & 318.725 \\
$\mathrm{~T}_{5}$ & 6.18 & 2.16 & 0.14 & 0.27 & 368.14 \\
\multicolumn{1}{c}{$\mathrm{T}_{6}$} & 6.02 & 1.97 & 0.16 & 0.44 & 0.32 \\
\hline Mean & 6.25 & 1.72 & 0.12 & & \\
\hline
\end{tabular}

$\mathrm{T}_{1}=$ Peanut alone; $\mathrm{T}_{2}=$ Sweetpotato alone; $\mathrm{T}_{3}=$ Peanut planted at the same time with sweetpotato; $\mathrm{T}_{4}=$ Peanut planted 1 week before intercrop with sweetpotato; $\mathrm{T}_{5}=$ Peanut planted 2 weeks before intercrop with sweetpotato; $\mathrm{T}_{6}=$ Peanut planted 3 weeks before intercrop with sweetpotato.

Table 2. Agronomic characteristics of peanut as influenced by time of planting sweetpotato as intercrop.

\begin{tabular}{|c|c|c|c|c|}
\hline \multirow{2}{*}{ Treatments } & \multicolumn{2}{|c|}{ Days from planting to } & \multirow{2}{*}{ LAI } & \multirow{2}{*}{$\begin{array}{c}\text { Fresh Herbage } \\
\text { Yield } \\
\left(\mathrm{t} \mathrm{ha}^{1}\right)\end{array}$} \\
\hline & Flowering & Maturity & & \\
\hline $\mathrm{T}_{1}$ & 30.00 & $98.33 \mathrm{a}$ & $1.40 \mathrm{a}$ & 9.05 \\
\hline \multicolumn{5}{|l|}{$\mathrm{T}_{2}$} \\
\hline $\mathrm{T}_{3}$ & 29.67 & $97.67 \mathrm{ab}$ & $1.16 \mathrm{~b}$ & 7.58 \\
\hline $\mathrm{T}_{4}$ & 30.00 & $96.67 \mathrm{ab}$ & $1.14 \mathrm{~b}$ & 8.16 \\
\hline $\mathrm{T}_{5}$ & 29.67 & $97.33 \mathrm{ab}$ & $1.20 \mathrm{~b}$ & 10.68 \\
\hline $\mathrm{T}_{6}$ & 30.00 & $96.00 \mathrm{~b}$ & $1.22 \mathrm{~b}$ & 7.98 \\
\hline C.V\% & 2.80 & 0.64 & 5.91 & 21.65 \\
\hline
\end{tabular}

$\mathrm{T}_{1}=$ Peanut alone; $\mathrm{T}_{2}=$ Sweetpotato alone; $\mathrm{T}_{3}=$ Peanut planted at the same time with sweetpotato; $\mathrm{T}_{4}=$ Peanut planted 1 week before intercrop with sweetpotato; $\mathrm{T}_{5}=$ Peanut planted 2 weeks before intercrop with sweetpotato $; \mathrm{T}_{6}=$ Peanut planted 3 weeks before intercrop with sweetpotato.

Peanut alone $\left(T_{1}\right)$ had significantly higher LAI of 1.40 than those peanut intercropped with sweetpotato regardless of the time of planting of the former. Higher LAI in peanut monocrop was due to the absence of intercrop; hence, no mutual shading occurred. Peanut planted alone normally grew with less competition for light. However, this result did show a significant difference in the total grain yield. This result conforms the findings of Aguelo (2003) that peanut 
planted alone produces high LAI but did not affect the total yield $\left(t \mathrm{ta}^{-1}\right)$. This result suggests that, the utilization of photosynthates was concentrated on the development of vegetative parts rather than in the reproductive parts. (Tschirhart, 2002).

\section{Yield and Yield Components and Harvest Index of Peanut as Main Crop}

Data on yield, yield components, and harvest index of peanut are shown in Table 3. Only the number of pods plant ${ }^{-1}$ and the number of seeds pod ${ }^{-1}$ were significantly $(p<0.05)$ affected by the time of planting of sweetpotato as an intercrop.

Peanut alone $\left(\mathrm{T}_{1}\right)$ and peanut + sweetpotato planted 3 weeks after peanut $\left(\mathrm{T}_{6}\right)$ had significantly $(p<0.05)$ higher number of pods plant ${ }^{-1}$ compared to peanut + sweetpotato planted at the same time $\left(\mathrm{T}_{3}\right)$. Treatments $\left(\mathrm{T}_{2}\right.$ and $\left.\mathrm{T}_{6}\right)$ were comparable to plants with sweetpotato intercropped planted 1 week after peanut $\left(\mathrm{T}_{4}\right)$ and sweetpotato intercrop planted 2 weeks after peanut $\left(T_{5}\right)$. This could be due to the minimum inter and intra-plant competition for growth factors when peanut was planted alone $\left(T_{1}\right)$ and when sweetpotato was intercrop planted 3 weeks after peanut $T_{6}$. This was because light was still abundant when sweetpotato vines were still short to cover the soil. Hence, there was less competition on growth factors specifically for light, space, and nutrients from vegetative stage up to early flowering stage. This result correlates the findings of Natureland (2000) that when peanut was planted ahead than sweetpotato it produced high leaf area index and resulted to higher number of marketable pods.

Table 3.Yield and yield components and harvest index of peanut as influenced by time of planting sweetpotato as intercrop.

\begin{tabular}{cccccc}
\hline Treatments & $\begin{array}{c}\text { Number of } \\
\text { pods plant }^{-1}\end{array}$ & $\begin{array}{c}\text { Number } \\
\text { of seeds } \\
\text { pod }^{-1}\end{array}$ & $\begin{array}{c}\text { Weight of } \\
1000 \text { seeds } \\
(\mathrm{g})\end{array}$ & $\begin{array}{c}\text { Dry Pod } \\
\text { Yield } \\
\left(\mathrm{t} \mathrm{ha}^{-1}\right)\end{array}$ & $\begin{array}{c}\text { Harvest } \\
\text { Index }\end{array}$ \\
\hline $\mathrm{T}_{1}$ & $21.20 \mathrm{a}$ & $2.23 \mathrm{a}$ & 575.50 & 1.77 & 0.17 \\
$\mathrm{~T}_{2}$ & - & - & - & - & - \\
$\mathrm{T}_{3}$ & $15.93 \mathrm{~b}$ & $1.67 \mathrm{c}$ & 622.76 & 1.36 & 0.15 \\
$\mathrm{~T}_{4}$ & $17.93 \mathrm{ab}$ & $2.00 \mathrm{ab}$ & 596.87 & 1.35 & 0.15 \\
$\mathrm{~T}_{5}$ & $19.27 \mathrm{ab}$ & $2.13 \mathrm{ab}$ & 571.90 & 1.67 & 0.14 \\
$\mathrm{~T}_{6}$ & $21.13 \mathrm{a}$ & $1.73 \mathrm{bc}$ & 580.03 & 1.62 & 0.17 \\
\hline $\mathrm{C} . \mathrm{V} \%$ & 7.58 & 7.88 & 9.94 & 26.43 & 24.79 \\
\hline
\end{tabular}

$\mathrm{T}_{1}=$ Peanut alone; $\mathrm{T}_{2}=$ Sweetpotato alone; $\mathrm{T}_{3}=$ Peanut planted at the same time with sweetpotato; $\mathrm{T}_{4}=$ Peanut planted 1 week before intercrop with sweetpotato; $\mathrm{T}_{5}=$ Peanut planted 2 weeks before intercrop with sweetpotato $; \mathrm{T}_{6}=$ Peanut planted 3 weeks before intercrop with sweetpotato.

Peanut + sweetpotato planted at the same time $\left(\mathrm{T}_{3}\right)$ produced significantly $(p<0.05)$ lower number of pods plant $t^{-1}$ than peanut alone $\left(\mathrm{T}_{2}\right)$. This was due to the fact that sweetpotato developed and grew more canopy ahead than peanut. This covered the area thus, affecting the flowering ability of peanut, and consequently, reduced the number of pods per plant. When subjected to shading, production of flowers was reduced (Natureland, 2000). 
Moreover, planting peanut alone $\left(\mathrm{T}_{1}\right)$ also had developed higher number of seeds per pod compared to peanut + sweetpotato planted at the same time $\left(\mathrm{T}_{3}\right)$. However, it was comparable to $\mathrm{T}_{4}$ (sweetpotato intercrop planted 1 week after peanut) and $\mathrm{T}_{5}$ (sweetpotato intercrop planted 2 weeks after peanut). This suggests that when sweetpotato is planted at the same time with peanut (maincrop), peanut could equally produce same yield as peanut planted alone.

\section{Agronomic Characteristics of Sweetpotato as Intercrop}

Data on agronomic characteristics of sweetpotato as intercrop to peanut is presented in Table 4. All the agronomic characteristics of sweetpotato except the LAI were significantly $(\mathrm{p}<0.05)$ affected by the time of planting sweetpotato as an intercrop to peanut. Planting sweetpotato at 1 to 3 weeks after peanut $\left(\mathrm{T}_{4}-\mathrm{T}_{6}\right)$ produced significantly $(\mathrm{p}<0.05)$ more lateral vines than simultaneous planting of peanut + sweetpotato and when planted alone $\left(\mathrm{T}_{2}\right)$. This result suggested that when sweetpotato (intercrop) was planted later than that of peanut (maincrop), it enhanced the production of more number of lateral vines and increased the vegetative growth of sweetpotato.

Table 4. Agronomic characteristics of the sweetpotato as intercrop to peanut.

\begin{tabular}{ccccc}
\hline Treatments & $\begin{array}{c}\text { No. of } \\
\text { lateral vines } \\
\text { plant }^{-1}\end{array}$ & $\begin{array}{c}\text { Length of main } \\
\text { vine at harvest } \\
(\mathrm{cm})\end{array}$ & LAI & $\begin{array}{c}\text { Fresh herbage } \\
\text { yield }\left(\mathrm{t} \mathrm{ha} \mathrm{a}^{1}\right)\end{array}$ \\
\hline $\mathrm{T}_{1}$ & - & - & - & - \\
$\mathrm{T}_{2}$ & $3.20 \mathrm{~b}$ & $283.06 \mathrm{~b}$ & 2.83 & $20.31 \mathrm{~b}$ \\
$\mathrm{~T}_{3}$ & $2.93 \mathrm{~b}$ & $368.78 \mathrm{a}$ & 2.39 & $25.00 \mathrm{a}$ \\
$\mathrm{T}_{4}$ & $4.67 \mathrm{a}$ & $345.35 \mathrm{a}$ & 2.42 & $29.95 \mathrm{a}$ \\
$\mathrm{T}_{5}$ & $4.80 \mathrm{a}$ & $334.63 \mathrm{a}$ & 2.67 & $26.94 \mathrm{a}$ \\
$\mathrm{T}_{6}$ & $5.47 \mathrm{a}$ & $353.07 \mathrm{a}$ & 2.02 & $20.92 \mathrm{~b}$ \\
\hline $\mathrm{C} . \mathrm{V} \%$ & 17.14 & 5.22 & 19.94 & 9.84 \\
\hline
\end{tabular}

Treatment means within column followed by a common letters and those without letters are not significantly different at $5 \%$ level, HSD. $\mathrm{T}_{1}=$ Peanut alone; $\mathrm{T}_{2}=$ Sweetpotato alone; $\mathrm{T}_{3}=$ Peanut planted at the same time with sweetpotato; $\mathrm{T}_{4}=$ Peanut planted 1 week before intercrop with sweetpotato; $\mathrm{T}_{5}=$ Peanut planted 2 weeks before intercrop with sweetpotato $; \mathrm{T}_{6}=$ Peanut planted 3 weeks before intercrop with sweetpotato.

Peanut planted earlier can help increase the nitrogen content of the soil through nitrogen fixation which made nitrogen available to the sweetpotato intercrop. This proves that planting peanut favors the vegetative growth of sweetpotato through the availability of nitrogen needed by sweetpotato for vine development Davis, (1989).

Sweetpotato as intercrop to peanut, regardless of time of planting the crops produced significantly $(p<0.05)$ longer sweetpotato vines compared to sweetpotato planted alone. This result could be attributed to the inherent characteristic of sweetpotato in response to the presence of legume crops, which make the sweetpotato vines to spread to look for more nutrients (Otadoy, 1989).

Planting sweetpotato intercrop at the same time with peanut $\left(\mathrm{T}_{3}\right)$ and planting 1 and 2 weeks after peanut $\left(\mathrm{T}_{4}\right.$ and $\mathrm{T}_{5}$ ) resulted in heavier herbage yield of sweetpotato compared to sweetpotato planted alone $\left(\mathrm{T}_{2}\right)$ and sweetpotato 
intercrop planted 3 weeks after peanut $\left(\mathrm{T}_{6}\right) . \mathrm{T}_{1}$ and $\mathrm{T}_{6}$ gave comparable herbage yield. Lower herbage yield in $\mathrm{T}_{6}$ might be due to interspecific competition between peanut and sweetpotato, causing sweetpotato to develop smaller leaves that make up its total herbage yield.

Baracoso (2004) observed that 1 row of sweetpotato planted alternately with 1 row of sweetcorn developed significantly lower LAI which resulted in lower herbage yield. On the other hand, 3 rows of sweetpotato planted alternately with 3 rows of sweetcorn developed higher LAI and heavier herbage yield comparable to sweetpotato monoculture due to the efficient utilization of soil nutrients, moisture, and solar energy. She stated that this condition enhanced the development of more physiological active and bigger leaves, resulting in higher herbage yield $\left(\mathrm{t} \mathrm{ha}^{-1}\right)$.

\section{Yield and Yield Components and Harvest Index of Sweetpotato as Intercrop}

Table 5 shows the yield and yield components and harvest index of sweetpotato as intercrop to peanut. Yield and yield components and harvest index of sweetpotato were not significantly $(\mathrm{p}<0.05)$ affected by time of planting peanut.

Sweetpotato alone $\left(\mathrm{T}_{2}\right)$ had the highest number of marketable and nonmarketable roots, weight of marketable and non-marketable roots, total root yield, and harvest index but statistically there were no significant $(p<0.05)$ differences among treatments. This means that sweetpotato planted together with peanut, regardless of time of planting, will give the same yield when sweetpotato is planted alone.

Table 5. Yield and yield components and harvest index of sweetpotato as intercrop to peanut.

\begin{tabular}{|c|c|c|c|c|c|c|}
\hline \multirow[b]{2}{*}{ Treatments } & \multicolumn{2}{|c|}{ Number of } & \multicolumn{2}{|c|}{ Weight of } & \multirow{2}{*}{$\begin{array}{c}\text { Total } \\
\text { root } \\
\text { yield } \\
\left(\mathrm{t} \mathrm{ha}^{-1}\right) \\
\end{array}$} & \multirow[b]{2}{*}{$\begin{array}{c}\text { Harvest } \\
\text { index }\end{array}$} \\
\hline & $\begin{array}{l}\text { Marketable } \\
\text { roots plot }^{-1}\end{array}$ & $\begin{array}{c}\text { Non- } \\
\text { marketable } \\
\text { roots plot }^{-1}\end{array}$ & $\begin{array}{l}\text { Marketable } \\
\text { roots plot }^{-1}\end{array}$ & $\begin{array}{c}\text { Non- } \\
\text { marketable } \\
\text { roots plot }^{-1}\end{array}$ & & \\
\hline $\mathrm{T}_{1}$ & - & - & - & - & - & - \\
\hline $\mathrm{T}_{2}$ & 44.67 & 54.33 & 6.33 & 0.71 & 7.04 & 0.30 \\
\hline $\mathrm{T}_{3}$ & 34.67 & 43.33 & 5.87 & 1.79 & 6.67 & 0.24 \\
\hline $\mathrm{T}_{4}$ & 31.33 & 41.67 & 3.99 & 1.39 & 5.38 & 0.15 \\
\hline $\mathrm{T}_{5}$ & 28.67 & 51.67 & 3.10 & 1.73 & 4.83 & 0.15 \\
\hline $\mathrm{T}_{6}$ & 25.33 & 31.67 & 3.57 & 1.33 & 4.90 & 0.18 \\
\hline C.V\% & 24.78 & 24.72 & 8.99 & 30.74 & 22.52 & 30.52 \\
\hline
\end{tabular}

Treatment means within column followed by a common letters and those without letters are not significantly different at $5 \%$ level, HSD. $\mathrm{T}_{1}=$ Peanut alone; $\mathrm{T}_{2}=$ Sweetpotato alone; $\mathrm{T}_{3}=$ Peanut planted at the same time with sweetpotato; $\mathrm{T}_{4}=$ Peanut planted 1 week before intercrop with sweetpotato; $\mathrm{T}_{5}=$ Peanut planted 2 weeks before intercrop with sweetpotato $; \mathrm{T}_{6}=$ Peanut planted 3 weeks before intercrop with sweetpotato.

The continuous supply of $\mathrm{N}$ from peanut promotes its vegetative growth and root formation to sweetpotato. The complementary advantage of legumes lies in their ability to utilize the atmospheric nitrogen in symbiosis with Rhizobium, a nitrogen fixing bacteria that lives in the root nodules. When the bacterium dies, the fixed nitrogen get released and shared by nearby plants (USDA, 1998).

\section{Land Equivalent Ratio}

Land Equivalent Ratio (LER) is a measure of the total land productivity. It is usually expressed as the sum of the fractions of the yield of a crop in association with other crops, to that of the monocrop. 
In general, all intercropping treatments $\left(\mathrm{T}_{3}-\mathrm{T}_{6}\right)$ had an LER greater than 1, which means that the intercropping scheme for this experiment is more advantageous than the sole cropping. This further suggests that intercropping peanut and sweetpotato is a good combination and can be planted regardless of timing of planting peanut and sweetpotato. An LER of more than one means that intercropping is more advantageous than mono-cropping in terms of total land productivity.

\section{Cost and Return Analysis}

The cost and return analysis of peanut and sweetpotato is presented in Table 7. Mean yields of both sweetpotato and peanut were used because there were no significant $(\mathrm{p}<0.05)$ differences on the total yields among the treatments. Data revealed that $T_{3}, T_{4}, T_{5}$ and $T_{6}$ (peanut and sweetpotato planted at the same time and peanut planted at 1,2 and 3 weeks ahead of sweetpotato) intercropped gave the same net income of Php 66,508.00.

Table 6. Land equivalent ratio of peanut as influenced by the time of planting sweetpotato as intercrop.

\begin{tabular}{lc} 
Treatments & $\begin{array}{c}\text { Land Equivalent Ratio } \\
\text { (LER) }\end{array}$ \\
\hline $\mathrm{T}_{1}=$ Peanut alone & - \\
$\mathrm{T}_{2}=$ Sweetpotato alone & - \\
$\mathrm{T}_{3}=$ Peanut planted at the same time with sweetpotato & 1.39 \\
$\mathrm{~T}_{4}=$ Peanut planted 1 week before intercrop with sweetpotato & 1.47 \\
$\mathrm{~T}_{5}$ = Peanut planted 2 weeks before intercrop with sweetpotato & 1.53 \\
$\mathrm{~T}_{6}=$ Peanut planted 3 weeks before intercrop with sweetpotato & 1.55
\end{tabular}

Table 7. Cost and return analysis of peanut and sweetpotato as influenced by time of planting the crops in an intercropping scheme.

\begin{tabular}{lccccc}
\hline Treatment & $\begin{array}{c}\text { Sweetpotato } \\
\text { yield } \\
\left(\mathrm{t} \mathrm{ha}^{-1}\right)\end{array}$ & $\begin{array}{c}\text { Peanut yield }(\mathrm{t} \\
\left.\mathrm{ha}^{-1}\right)\end{array}$ & $\begin{array}{c}\text { Gross income } \\
\text { (Php) } \\
(\text { combined) }\end{array}$ & $\begin{array}{c}\text { Total } \\
\text { expenses } \\
\text { (Php) }\end{array}$ & $\begin{array}{c}\text { Net income } \\
\text { (Php) }\end{array}$ \\
\hline $\mathrm{T}_{1}$ & - & 1.57 & $62,800.00$ & $26,710.00$ & $36,090.00$ \\
$\mathrm{~T}_{2}$ & 5.76 & - & $46,112.00$ & $32,290.00$ & $13,822.00$ \\
$\mathrm{~T}_{3}$ & 5.76 & 1.57 & $108,912.00$ & $42,410.00$ & $66,508.00$ \\
$\mathrm{~T}_{4}$ & 5.76 & 1.57 & $108,912.00$ & $42,410.00$ & $66,508.00$ \\
$\mathrm{~T}_{5}$ & 5.76 & 1.57 & $108,912.00$ & $42,410.00$ & $66,508.00$ \\
$\mathrm{~T}_{6}$ & 5.76 & 1.57 & $108,912.00$ & $42,410.00$ & $66,508.00$ \\
\hline
\end{tabular}

Price of peanut Php $40.00 / \mathrm{kg}$ and for sweetpotato Php $8.00 / \mathrm{kg}$

$\mathrm{T}_{1}=$ Peanut alone; $\mathrm{T}_{2}=$ Sweetpotato alone; $\mathrm{T}_{3}=$ Peanut planted at the same time with sweetpotato; $\mathrm{T}_{4}=$ Peanut planted 1 week before intercrop with sweetpotato; $T_{5}=$ Peanut planted 2 weeks before intercrop with sweetpotato $; \mathrm{T}_{6}=$ Peanut planted 3 weeks before intercrop with sweetpotato. 


\section{CONCLUSIONS}

Based on the results of the study, the following conclusions can be drawn;

1. Peanut's maturity, LAI, number of pods plant ${ }^{-1}$ and number of seeds pod ${ }^{-1}$ were significantly improved by time of planting sweetpotato as intercrop.

2. It is appropriate to plant peanut and sweetpotato together at 1 to 3 weeks before planting sweetpotato as intercrop.

3. A high net income of Php 66,508.00 was obtained from peanut and sweetpotato planted together regardless of time (1-3 weeks) of planting the crops in an intercropping scheme.

\section{RECOMMENDATION}

For effective land utilization, peanut and sweetpotato can be planted together at 1 to 3 weeks before planting sweetpotato as intercrop.

\section{REFERENCES}

AGUELO, G.C. 2003. Spatial arrangement of sorghum-peanut combination under intercropping scheme. Undergraduate Thesis. Visca, Baybay, Leyte. 64pp.

BADALUCCO, L. and P. KUIKMAN. 2002. Mineralization and Immobilization in the Rhizophere: Biochemistry and Organic substances at the Soil-Plant interface. Eds. R. Pinton, et al. New York: Marcel Dekker.159-196 pp.

BARACOSO, A.A. 2004. Sweetpotato-sweetcorn combination under different intercropping schemes. Undergraduate Thesis. Visca, Baybay, Leyte. 68 pp.

BLOMHOFF R, CARLSEN MH, ANDERSEN LF and JACOBS DR Jr. 2006. Health benefits of nuts: potential role of antioxidants. Br J. Nutr. Suppl2:S5260.2006. PMID:17125534.

BRADY, N.C 1990. The Nature and Properties of Soil. The MacMillan Publication. Co. Inc., New York, 620 pp.

ESCALADA, R.G., A.B. ESCASINAS and M.E. BALIAD. 1983. Cultural management of sweetpotato, cassava, and gabi under various multiple cropping schemes utilizing legumes as source of nitrogen. Ann. of Trop. Res. 6 (3): 63-76.

DAVIS, J. M. 1989. Growth and Yield of Sweetpotato Intercropped with Peanut in Hilly Areas. Undergraduated Thesis. Visca, Baybay, Leyte.42 pp.

GECKER, J., U. MEYER. 1995. Phosphate acquisition by red clover and black mustard on a humicpodsol. J. Plant Nutr. 18, 2409-2429.

NATURELAND. 2000. Organic Farming in the'Tropics and Subtropics. Vol.1. $1^{\text {st }}$ edition http://www.naturland.de/fileadmin/MDB/documents /Publication/English/peanuts.

OTADOY, T.S. 1989. Response of Sweetpotato to Varying Time of Planting Cowpea as an Intercrop. Undergraduate thesis, Visca, Baybay, Leyte. 115 pp.

PCARRD. 2005 . Vegetables, Legumes and Rootcrops. http:/www.pcarrd.dost.gov.ph/commodities/velero/index.pl option $=$ content $\&$ task $=$ view $\&$ id $=13 \& 1$ temid $=36$ 
PCARR. 1980. Standard Methods of Analysis for Soil. Plant Tissue of Water and fertilizer. Farm Resource and System Research Div. Los Baños. 164 pp.

TSCHIRHART, J. (2002). Resource Competition among Plants: From Maximizing Individuals to Community Structure. Ecological Modeling148 (2002) 191-212. Pdf uwadmnweb.uwyo.edu/econfinance/Tschirhart/cmmntypprrev.pdf

USDA. 1998. Legumes and Soil Quality: Soil quality-Agronomy Technical Note no. 6. http://soils.usda.gov/sqi/management/files/sq_atn_6.pdf. 